\title{
Navigated Total Knee Arthroplasty in Cases with Intra- and Extraarticular Deformities
}

Received: December 13, 2016; Accepted: December 16 2016; Published: December 20, 2016

\section{Editorial}

Total knee replacement is a highly effective method for treatment of posttraumatic arthritis, widespread in the world. However, many patients undergoing total knee replacement remain dissatisfied with the outcome. Number of failures is due to mechanical reasons, which include the malposition of the components, which effect to the mechanical axis, the violation of the components rotation, as well as the imbalance of ligaments of the knee joint.

Some authors consider, that the deviation of the mechanical axis of the limb after total knee replacement more, than $3^{\circ}$ decreases long-term results and increases rate of implant loosening.

According to the literature data, computerized navigation can improve the components installation accuracy of the knee joint endoprosthesis and improve clinical outcome [1-10]. Other authors did not find statistically significant differences in groups of patients using computerized navigation and standard techniques [11-22].

The injury role in arthritis development is very high. All kind cartilage injury especially intraarticular fractures lead to degenerative processes.

Benazzo et al. [23] showed indications and the results of TKA in chronic and acute trauma. Indications for TKA in acute fractures are complex and combined injury, old age and osteoporosis. 6 patients were operated, $84 \%$ good and excellent results. Paratt et al. reported fracture locations: tibia $55 \%$, femur $27 \%$, combined $2 \%$, patella $16 \%$. Patiens had previous $92 \%$ surgery ORIF, $15 \%$ infection history, $10 \%$ insufficient ligaments, $44 \%$ stiff knees. Number of infection after posttraumatic TKA increase especially in cases after ORIF.

Posttraumatic lower limb deformities are the serious group of arthritis patients with femur or tibial shaft curvature in frontal, axial and coronal position. We can examine shortening, rotation and all kind lower limb deformation. Arthritis in these patients can be the reason of only shaft fractures, but a combination of the shaft and intraarticular injury. TKA must be performed with severe curved lower limb axis. But we should restore mechanical axis in TKA. Some authors supposed, that navigated TKA valuable option for patients with deformed femurs [19].

The grate difficulties are intraarticular deformities. In such cases

\section{Murylev VY1,2, Rukin YA ${ }^{1}$ and Muzychenkov AV ${ }^{1,2}$}

1 I.M.Sechenov First Moscow State Medical University, Moscow, Russia

2 S.P. Botkin Moscow City Clinical Hospital, Moscow, Russia

Corresponding author: Murylev VY

nmuril@yandex.ru

Murylev VY, I.M. Sechenov First Moscow State Medical University, Russia.

Citation: Murylev VY, Rukin YA, Muzychenkov AV. Navigated Total Knee Arthroplasty in Cases with Intra- and Extraarticular Deformities N. J Bone Rep Recomm. 2016, 2:4.

for knee balancing we should use more constraint components, than for extra articular deformities. In femur defects CCK components are necessary for extension gap and joint line restoration to avoid patella bacha [21]. In tibia defects we need constraint too. Sometimes we have both articular parts damaged and hing prosthesis will be the choice. In some literature we found information, that severity of virus deformity did not affect the accuracy of image-free computer navigated TKA [13].

Sometimes careful preoperative planning shows us impossibility to perform right component positioning with standard instrumentation. It depends on bony defects, ligaments, shaft malunion and soft tissue disorders. Of course, we need longstanding X-rays and it helps us, CT also is very useful. But convenient surgery will be unsatisfied. It's impossible to use intramedullary guide, to check each millimeters, to resect in correct degrees and levels.

As we marked earlier navigation system helps us to establish all components in the best position. But in literature we met articles about normal arthritis or difficult virus or valgus deformities. There are few data about posttraumatic cases. But in some cases limb deformity is very seriouse and angls can not allow us to resect and to save ligaments. In such cases surgeons should decide what to do, convinient TKA, osteotomy or navigated TKA. By our opinion, orthopeadic surgeons should continue researches with navigated TKA in posstraumatic limb deformities and probably can reduce revision risk [24]. 


\section{References}

1 Chin PL, Yang KY, Yeo SJ, Lo NN (2005) Randomized control trial comparing radiographic total knee arthroplasty implant placement using computer navigation versus conventional technique. J Arthroplasty 20: 618-626.

2 Colle F, Lopomo N, Bruni D, Visani A, lacono F, et al. (2014) Analysis of knee functional flexion axis in navigated TKA: Identification and repeatability before and after implant positioning. Knee Surg Sport Traumatol Arthrosc 22: 694-702.

3 Daubresse F, Vajeu C, Loquet J (2005) Total knee arthroplasty with conventional or navigatedtechnique: comparison of the learning curves in a community hospital. Acta Orthop Belg 71: 710-713.

4 Ensini A, Catani F, Leardini A, Romagnoli M, Giannini S (2007) Alignments and clinicalresults in conventional and navigated total knee arthroplasty. Clin Orthop 457: 156-162.

5 Zhang GQ, Chen JY, Chai W, Liu M, Wang Y (2011) Comparison Between Computer-Assisted-Navigation and Conventional Total Knee Arthroplasties in Patients Undergoing Simultaneous Bilateral Procedures. J Bone Joint Surg Am 93: 1190-1196.

6 Hoffart HE, Langenstein E, Vasak N (2012) A prospective study comparing the functional outcome of computer-assisted and conventional total knee replacement. J Bone Joint Surg Br 94: 194-199.

7 Jeffery RS, Morris RW, Denham RA (1991) Coronal alignment after total knee replacement. J Bone Joint Surg Br 73: 709-714.

8 Kavalerskiy GM, Murylev VY, Rukin YA, Elizarov PM, Terentiev DI (2012) Total knee arthroplasty using computer navigation. J Depart Traum Orth 2: 8-11.

9 Kavalerskiy GM, Murylev VY, Rukin YA, Lichagin AV, Elizarov PM (2012) Possibilities of computer navigation in primary total knee arthroplasty. J Traum Orth 4: 27-31.

10 Kim YH, Kim JS, Yoon SH (2007) Alignment and orientation of the components in total knee replacement with and without navigation support: a prospective, randomized study. J Bone Joint Surg $\mathrm{Br} 89$ : 471-476.

11 Kim YH, Park JW, Kim JS (2012) Computer-Navigated Versus Conventional Total Knee Arthroplasty. J Bone Joint Surg Am 94: 2017-2024.

12 Lützner J, Krummenauer F, Wolf C, Günther K, Kirschner S (2008) Computer-assisted and conventional total knee replacement. J Bone Joint Surg Br 90: 1039-1044.
13 Maniwa K, Ishibashi Y, Tsuda E, Yamamoto Y, Inoue R, et al. (2013) Accuracy of image-free computer navigated total knee arthroplasty is not compromised in severely deformed varus knees. J Arthroplasty 28: $802-806$

14 Matziolis G, Krocker D, Weiss U, Tohtz S, Perka C (2007) A prospective, randomized study of computer-assisted and conventional total knee arthroplasty: three-dimensional evaluation of implant alignment and rotation. J Bone Joint Surg Am 89: 236-243.

15 Parratte S, Pagnano MW, Trousdale RT, Berry DJ (2010) Effect of postoperative mechanical axis alignment on the fifteen-year survival of modern, cemented total knee replacements. J Bone Joint Surg Am 92: 2143-2149.

16 Rand JA, Coventry MB (1988) Ten-year evaluation of geometric total knee arthroplasty. Clin Orthop Relat Res 232: 168-173.

17 Ritter MA, Faris PM, Keating EM, Meding JB (1994) Postoperative alignment of total knee replacement. Its effect on survival. Clin Orthop Relat Res 299: 153-156.

18 Schnurr C, Güdden I, Eysel P, König DP (2012) Influence of computer navigation on TKA revision rates. Int Orthop 36: 2255-2260.

19 Sparmann M, Wolke B, Czupalla H, Banzer D, Zink A (2003) Positioning of total knee arthroplasty with and without navigation support: a prospective, randomised study. J Bone Joint Surg [Br] 85: 830-835.

20 Spencer JM, Chauhan SK, Sloan K, Taylor A, Beaver RJ (2007) Computer-navigationversus conventional total knee replacement: no difference in the functional results at two years. J Bone Joint Surg $\mathrm{Br}$ 89: 477-480.

21 Stiehl JB, Heck DA (2015) How Precise Is Computer-navigated Gap Assessment in TKA? Clin Orthop Relat Res 473: 115-118.

22 Todesca A, Garro L, Penna M, Bejui-Hugues J (2016) Conventional versus computer-navigated TKA: a prospective randomized study. Kne Surg Spors Trau Arthrosc 1: 6.

23 Benazzo F, Rossi SMP, Ghiara M (2014) Total knee replacement in acute and chronic traumatic events. Injury 45: S98-S104

24 Shao J, Zhang W, Jiang Y, Wang Q, Chen Y, et al. (2012) Computernavigated TKA for the treatment of osteoarthritis associated with extra-articular femoral deformity. Orthopedics 35: 794-799. 